\title{
PENGARUH PERSEPSI KUALITAS, NAMA MEREK DAN BRAND AWARENESS TERHADAP KEPUTUSAN PEMBELIAN
}

\section{EFFECT OF QUALITY PERCEPTION, BRAND NAME, AND AWARENESS BRAND ON PURCHASE DECISIONS}

\author{
Eris Dwiyanti, Nurul Qomariah, Wenny Murtalining Tyas \\ Fakultas Ekonomi Universitas Muhammadiyah Jember \\ Email: Erisdwiyanti18@gmail.com, nurulqomariah@unmuhjember.ac.id, \\ wennymurtaliningtyas@unmuhjember.ac.id
}

\begin{abstract}
ABSTRAK
Penelitian ini bertujuan untuk menganalisis pengaruh Pengaruh Persepsi Kualitas, Nama Merek, dan Brand Awareness Terhadap Keputusan Pembelian Sabun Cuci Rinso pada Mahasiswa Fakultas Ekonomi Angkatan 2014 Universitas Muhammadiyah Jember. jenis penelitian deskriptif kuantitatif dengan desain penelitian eksplanatori. Populasi dalam penelitian ini adalah seluruh Mahasiswa Fakultas Ekonomi Angkatan 2014 Universitas Muhammadiyah Jember, yakni sebesar 555 Mahasiswa. Sampel yang diambil adalah 83 responden dengan tekhnik accidental sampling. Alat analisis menggunakan regresi linier berganda. Hasil penelitian menunjukkan bahwa persepsi kualitas, nama merek dan brand awareness secara parsial berpengaruh signifikan terhadap keputusan pembelian. Analisis koefisien determinasi menunjukkan bahwa 59,7 \% Keputusan Pembelian dipengaruhi oleh persepsi kualitas, nama merek, dan brand awareness.
\end{abstract}

Kata Kunci: Persepsi kualitas, nama merek, brand awareness, keputusan pembelian.

\begin{abstract}
This study aims to analyze the influence of Quality Perception, Brand Name, and Brand Awareness Against Purchasing Decision of Rinso Washing Soap at Student of Faculty of Economics, Force 2014 University of Muhammadiyah Jember. type of quantitative descriptive research with explanatory research design. Population in this research is all student of Faculty of Economics Force 2014 University of Muhammadiyah Jember, that is equal to 555 Students. Samples taken were 83 respondents with accidental sampling technique. Analyzer uses multiple linear regression. The results showed that the perception of quality, brand name and brand awareness partially significant effect on purchasing decisions. Coefficient of determination analysis shows that 59,7\% Purchasing Decision influenced by perception of quality, brand name, and brand awareness.
\end{abstract}

Keywords: Perception of quality, brand name, brand awareness, purchasing decision.

\section{PENDAHULUAN}

Dalam perkembangan dunia usaha yang begitu pesat dewasa ini menjadi salah satu penyebab persaingan antar perusahaan semakin kompetitif, banyak perusahaan yang berlomba-lomba menguasai pasar sehingga berbagai banyak cara dilakukan oleh pihak 
perusahaan supaya bisa menduduki posisi sebagai market leader. Selain itu perkembangan dunia usaha juga didorong oleh kebutuhan masyarakat yang semakin kompleks. Kebutuhan itupun saat ini telah menjadi suatu gaya hidup yang harus terpenuhi oleh masyarakat modern. Salah satu kebutuhan yang yang harus terpenuhi saat ini adalah kebutuhan untuk hidup bersih.

Perkembangan kebutuhan diatas menjadi kesempatan perusahaan untuk memperluas ladang bisnisnya khususnya industri yang bergerak pada bidang produkproduk pembersih. Persaingan yang ketat mengubah pola pikir masyarakat untuk memilih produk yang baru. kebutuhan produk yang memiliki kesamaan kegunaan dan bentuk kemasan salah satunya produk sabun cuci. banyak masyarakat beranggapan bahwa membeli suatu produk tidak hanya berhenti pada satu titik. semakin banyak jenis dan merek yang beredar dipasaran konsumen pun semakin jeli dan kritis dalam memilih produk yang ada. konsumen akan menggunakan produk yang menurut persepsinya terbaik (Bimal et.al,2012).

Industri produk sabun cuci pakaian di indonesia saat ini berkembang pesat. terbukti telah banyak beredar berbagai merek sabun cuci yang ada di pasaran, seperti: rinso, Industri produk sabun cuci pakaian di indonesia saat ini berkembang pesat. terbukti telah banyak beredar berbagai merek sabun cuci yang ada di pasaran, seperti: rinso, daia, attack, so klin dan masih banyak lagi merek yang lainnya yang bervariasi. keanekaragaman sabun cuci pakaian yang ada sekarang ini memudahkan konsumen dalam memilih sabun cuci yang mereka butuhkan. sabun cuci pakaian sudah tertanam dibenak konsumen, karena itu para produsen berlomba-lomba untuk memberikan kualitas terbaik dari produknya.

Fenomena tersebut dapat dilihat dari produk nyata yang sudah ada di pasaran yaitu pada produk sabun cuci pakaian seperti: rinso, daia, attack, so klin dan masih banyak lagi merek yang lainnya serta berbagai variasi, mulai dari detergen bubuk, cair, dan bahkan produsen juga memasarkan detergen khusus untuk mesin cuci (matic). seiring perkembangan usaha banyak inovasi- inovasi baru sabun pencuci pakaian yang lebih terdepan sehingga mengubah pola pikir masyarakat untuk memilih produk yang baru. Sabun pencuci yang beraneka ragam ini mendorong konsumen untuk memilih salah satu produk yang sudah banyak ditawarkan dipasaran yang menurut persepsi konsumen merupakan sabun cuci yang mempunyai nilai tambah (vallue added) dan ideal digunakan. 
Melalui proses tersebut, dapat dilihat bahwa kekuatan merek terletak pada kemampuannya untuk mempengaruhi perilaku pembelian (Arif Rahman, 2010).

Ada berbagai macam-macam merek sabun cuci yang mendapat penghargaan dan diberikan kepada merek-merek terbaik pilihan konsumen. Berdasarkan hasil riset terhadap konsumen di Indonesia tahun 2016-2017.

Tabel 1. Top Brand Award Produk Sabun Cuci Tahun 2016

\begin{tabular}{clcl}
\hline MEREK & \multicolumn{1}{c}{ PERUSAHAAN } & TBI & TOP \\
\hline Rinso & PT.Unilever Indonesia & $50,5 \%$ & TOP \\
Daia & PT.Wings Surya & $18,2 \%$ & TOP \\
Attack & PT. Kao Indonesia & $12,4 \%$ & TOP \\
So-Klin & PT.Wings Surya & $8,0 \%$ & \\
\hline
\end{tabular}

Sumber : Survey top brand -Top brand award- survey result - top brand index tahun 2016 fase 1 .

Berdasarkan tabel 1. menunjukkan bahwa dari 3 (tiga) industri produk sabun cuci pakaian telah memasarkan 4 (empat) produk yang mendapatkan predikat Top Brand Award pada tahun 2016. TBI sabun cuci pakaian urutan pertama adalah sabun cuci rinso dengan persentase 50,5\%, urutan kedua adalah sabun cuci daia dengan persentase $18,2 \%$ dan urutan ketiga adalah sabun cuci attack dengan persentase 12,4\%. Sedangkan sabun cuci so-klin menempati posisi terakhir dengan persentase 8,0\% dan tidak mendapatkan predikat top.

Tabel 2. Top Brand Award Produk Sabun Cuci Tahun 2017

\begin{tabular}{clcc}
\hline MEREK & \multicolumn{1}{c}{ PERUSAHAAN } & TBI & TOP \\
\hline Rinso & PT.Unilever Indonesia & $49.0 \%$ & TOP \\
Daia & PT.Wings Surya & $17.2 \%$ & TOP \\
Attack & PT. Kao Indonesia & $11,5 \%$ & TOP \\
So-Klin & PT.Wings Surya & $8,7 \%$ & \\
\hline Sumber : Survey top brand -Top brand award- survey result - top brand index \\
tahun 2017 fase 1
\end{tabular}

Berdasarkan tabel 2. diatas menunjukkan bahwa dari 3 (tiga) industri produk sabun cuci pakaian telah memasarkan 4 (empat) produk yang mendapatkan predikat Top Brand Award pada tahun 2017. TBI sabun cuci pakaian urutan pertama adalah sabun cuci rinso dengan persentase $49.0 \%$, urutan kedua adalah sabun cuci daia dengan persentase 17.2\%, dan urutan ketiga adalah sabun cuci attack dengan persentase 11,5\%, Sedangkan sabun cuci so-klin menempati posisi terakhir dengan persentase $8,7 \%$ dan tidak mendapatkan predikat top. 
Semakin meningkatnya persaingan antara produk-produk sejenis, maka perusahaan yang satu dengan yang lain saling bersaing merebutkan konsumen. Perusahaan yang mampu menciptakan dan mempertahankan pelanggan akan sukses dalam persaingan. Setiap perusahaan berusaha untuk memahami perilaku konsumen pada pasar sasaran untuk kelangsungan hidup perusahaan. Konsumen akan dihadapkan oleh produk yang menurut persepsi mereka ideal. Dalam kaitannya dengan produk sabun cuci pakaian, konsumen tidak hanya memperhatikan harga yang ditawarkan, tetapi penilaian kosumen akan produk tersebut. Keputusan pembelian sangat penting bagi sebuah perusahaan, karena dengan adanya keputusan pembelian perusahaan mempunyai peranan guna merancang produk, menentukan pesan, pengalokasian biaya anggaran promosi sesuai membuat program pemasaran sesuai dengan pembeli. Dengan merancang berbagai macam peranan tersebut maka akan berdampak pada keinginan konsumen untuk melakukan pembelian.

Harmani (2008) menyatakan keputusan pembelian merupakan proses pengintegrasian yang mengkombinasikan untuk mengevaluasi dua atau lebih perilaku alternatif, dan memilih salah satu diantaranya. dalam mengamati sikap konsumen maka perusahaan dapat pula menentukan bagaimana pengaruh sikap konsumen dalam pengambilan keputusan. Banyak factor yang mempengaruhi keputusan pembelian, salah satunya adalah persepsi kualitas.

Setyaji (2008) persepsi kualitas adalah persepsi pelanggan terhadap keseluruhan kualitas atau keunggulan dari suatu produk yang berkaitan dengan apa yang diharapkan oleh pelanggan. Persepsi kualitas menggambarkan respon keseluruhan konsumen terhadap kelebihan dan kekurangan suatu merek. Respon ini adalah persepsi dari komunikasi pelanggan-pelanggan lain yang pernah membeli produk maupun konsumen itu sendiri tentang kualitas atau keunggulan merek. Mayasari (2011), Tambunan (2012), Firdaus (2015) Inayati dan Wahyuni (2017) telah meneliti pengaruh persepsi kualitas terhadap keputusan pembelian, menyatakan bahwa persepsi kualitas mempunyai pengaruh yang signifikan terhadap keputusan pembelian.

Nama merek sangat berperan penting dalam kesuksesan sebuah perusahaan, nama merek yang mudah diingat akan mendorong konsumen untuk memutuskan pembelian. Dengan memperkuat nama merek disisi lain perusahaan harus menanamkan kesadaran 
merek (brand awareness) di benak konsumen terhadap merek yang dikeluarkan oleh perusahaan. Mayasari, (2011) menyatakan brand awareness adalah kekuatan sebuah merek dalam pikiran (ingatan) pelanggan. brand awareness adalah kemampuan calon pembeli atau konsumen untuk mengenali maupun mengingat sebuah merek. Dalam hal ini tentunya bisa meliputi nama, gambar/ logo, serta slogan tertentu yang digunakan para pelaku pasar untuk mempromosikan produk-produknya. Dengan demikian, adanya kesadaran merek maka konsumen akan mengenali dan mengingat kembali suatu merek dari kategori produk yang akan dibeli. Kumalasari (2013), Mayasari (2011), Firdaus (2015), Ambarini dkk (2016), Inayati dan Wahyuni (2017) telah meneliti pengaruh brand awareness terhadap keputusan pembelian, menyatakan bahwa brand awareness mempunyai pengaruh yang signifikan terhadap keputusan pembelian.

Fakultas Ekonomi adalah salah satu dari 9 (sembilan) fakultas yang ada di Universitas Muhammadiyah Jember. Kebutuhan akan sabun cuci sangat penting bagi mahasiswa untuk menunjang penampilannya saat melakukan aktifitas sehari-hari supaya tetap tampil harum dan bersih. Pemilihan sabun cuci yang digunakan mahasiswa untuk kebutuhan mencuci pakaian sangatlah penting, salah satunya adalah sabun cuci pakaian rinso. Rinso adalah salah satu sabun cuci merek pertama dalam pasar detergen di Indonesia dan selalu terdepan dalam melakukan inovasi di pasaran. Merek rinso ini sudah melekat dibenak konsumen yang menggunakan produk tersebut ketika dihadapkan pada situasi keputusan untuk membeli produk sabun pencuci pakaian. lebih lanjut bahwa konsumen mungkin akan menggunakan aturan dalam keputusan pembeliannya. Dari uraian ditas maka tujuan penelitian ini adalah :

1. Untuk menganalisis pengaruh persepsi kualitas terhadap keputusan pembelian sabun cuci pakaian rinso.

2. Untuk menganalisis pengaruh nama merek terhadap keputusan pembelian sabun cuci pakaian rinso.

3. Untuk menganalisis pengaruh brand awareness terhadap keputusan pembelian sabun cuci pakaian rinso.

4. Untuk menganalisis persepsi kualitas, nama merek, dan brand awareness berpengaruh terhadap keputusan pembelian sabun cuci pakaian rinso 


\section{TINJAUAN PUSTAKA}

\section{Persepsi Kualitas}

Persepsi kualitas terhadap merek menggambarkan respon keseluruhan pelanggan terhadap kualitas dan keunggulan yang ditawarkan merek. Respon ini adalah persepsi yang terbentuk dari pengalaman pelanggan selama berinteraksi dengan merek melalui komunikasi yang dibangun oleh pemasar. Tentu saja kondisi seperti ini harus terus dijaga melalui pengembangan kualitas secara berkesinambungan (Sadat, 2009).

\section{Nama merek}

Kotler dan Keller (2009) merek adalah: nama, istilah, lambang, atau desain, atau kombinasinya, yang dimaksudkan untuk mengidentifikasi barang atau jasa dari salah satu penjual atau kelompok penjual dan mendiferensiasikan mereka dari pesaing. Melalui nama merek yang satu dapat dibedakan dengan merek yang lain atau dengan kata lain nama merek menjadi sesuatu yang penting dalam proses identifikasi (Sadat, 2009).

\section{Brand Awareness}

Kotler dan Keller (2008) menyatakan kesadaran merek adalah kemampuan konsumen untuk mengidentifikasi merek dalam kondisi berbeda, seperti tercermin oleh pengenalan merek mereka atau prestasi pengingatan. (Aaker, 2013) menambahkan kesadaran merek sebagai kemampuan seseorang untuk mengingat dan megenali merek terhadap produk yang telah mencapai tingkat kesadaran yang dominan. Kesadaran merek dapat diukur dari mengenali merek, mengingat merek, dan mudah mengingat logo atau simbol merek. Kemampuan konsumen untuk mengatur dan mengingat merek dikenal sebagai brand awareness (Aaker dalam Moisescu: 2013).

\section{Keputusan Pembelian}

(Harmani, 2008) menyatakan bahwa keputusan pembelian merupakan proses pengintegrasian yang mengkombinasikan untuk mengevaluasi dua atau lebih perilaku alternatif, dan memilih salah satu diantaranya. Proses keputusan pembelian menurut (Kotler, 2008), terdiri lima tahap, yaitu pengenalan kebutuhan, pencarian informasi, evaluasi alternatif, keputusan pembelie3an, pasca pembelian. Keputusan pembelian menunjuk arti kesimpulan terbaik konsumen untuk melakukan pembelian. Konsumen melakukan kegiatan kegiatan dalam mencapai kesimpulanya. 


\section{METODE PENELITIAN}

\section{Desain Penelitian}

Penelitian ini menggunakan pendekatan kuantitatif. Metode survei dipilih sebagai sumber data primer. Metode survei fokus pada pengumpulan data responden yang memiliki informasi tertentu, sehingga memungkinkan peneliti untuk menyelesaikan masalah. Tipe penelitian ini menggunakan penelitian ekspalatori yang bersifat eksplanatory research. Penelitian eksplanatory merupakan tipe penelitian yang digunakan untuk menjelaskan hubungan kausal.

\section{Identifikasi Variabel}

Sugiyono (2012) menyatakan bahwa variabel penelitian adalah suatu atribut atau sifat atau nilai dari uang, objek, atau kegiatan yang mempunyai variasi tertentu yang diterapkan oleh peneliti untuk dipelajari dan kemudian ditarik kesimpulannya. Dalam penelitian ini terdiri dari empat variabel :

a. Variabel terikat (dependent variable)

Variabel dependen disebut juga variabel output, kriteria, konsekuen. Dalam bahasa indonesia disebut variabel terikat. Variabel terikat merupakan variabel yang dipengaruhi atau yang menjadi akibat, karena adanya variabel bebas. (Sugiyono, 2009). variabel dependen dalam penelitian ini adalah : Keputusan Pembelian (Y).

a. Variabel Bebas (Independent Variable)

Variabel ini sering disebut variabel stimulus, prediktor, antecedent. Dalam bahasa indonesia disebut sebagai variabel bebas. Variabel bebas merupakan variabel yang mempengaruhi atau yang menjadi sebab perubahannya atau timbulnya variabel dependen (Sugiyono, 2009). Variable independen adalah variabel yang menjelaskan mengenai cara sebuah masalah dipecahkan dalam suatu analisis. Variabel independen dalam penelitian ini adalah :
a. Persepsi Kualitas
$:\left(\mathrm{X}_{1}\right)$
b. Nama Merek
$:\left(\mathrm{X}_{2}\right)$
c. Brand Awareness
$:\left(\mathrm{X}_{3}\right)$

\section{Populasi dan Sampel}

Untuk memperoleh hasil data yang valid maka perlu di lakukan penarikan sampel dari suatu populasi yang hendak diteliti. (Sugiyono, 2008) populasi adalah wilayah generalisasi yang terdiri atas: obyek/subyek yang mempunyai kualitas dan 
karakteristik tertentu yang ditetapkan oleh peneliti untuk dipelajari dan kemudian ditarik kesimpulannya. Sampel adalah bagian dari jumlah dan karakteristik yang dimiliki oleh populasi tersebut (Sugiyono, 2008). Sampel dalam penelitian ini adalah Mahasiswa Fakultas Ekonomi Universitas Muhammadiyah Jember Angkatan 2014 yang pernah menggunakan produk sabun cuci Rinso dengan jumlah sampel sebanyak 83 atas dasar rumus Slovin.

\section{Uji Validitas}

Uji validitas bertujuan untuk mengetahui sejauh mana validitas data yang diperoleh dari penyebaran kuisioner. Uji validitas sebagai alat ukur dalam penelitian ini, yaitu menggunakan korelasi product moment pearson's, yaitu dengan cara mengkorelasikan tiap pertanyaan dengan skor total, kemudian hasil korelasi tersebut dibandingkan dengan angka kritis taraf signifikan 5\%, dengan mengunakan rumus, (Prayitno, 2010).

\section{Uji Reliabilitas}

Uji reliabilitas digunakan untuk menguji kemampuan suatu hasil pengukuran relatif konsisten apabila pengukurannya diulangi dua kali atau lebih (Prayitno, 2010). Reliabilitas berkonsentrasi pada masalah akurasi pengukuran dan hasilnya. Dengan kata lain reliabilitas menunjukkan seberapa besar pengukuran kendali terhadap subjek yang sama.

\section{Analisis Regresi Linier Berganda}

Analisis Regresi Linier Berganda merupakan salah satu analisis yang bertujuan untuk mengetahui pengaruh suatu variable terhadap variabel lain. Dalam analisis regresi variabel yang mempengaruhi disebut dependent variable (variablel terikat). Jika dalam persamaan regresi hanya terdapat salah satu variable terikat, maka disebut regresi sederhana, sedangkan jika variable bebasnya lebih dari satu, maka disebut sebagai persamaan regresi berganda (Prayitno 2010).

\section{Koefisien Determinasi $\left(\mathbf{R}^{2}\right)$}

Menurut Ghozali (2012) koefisien determinasi $\left(\mathrm{R}^{2}\right)$ merupakan alat untuk mengukur seberapa jauh kemampuan model dalam menerangkan variabel-variabel dependen. Nilai koefisien detreminasi adalah antara nol atau satu. Jika $\left(\mathrm{R}^{2}\right)$ yang diperoleh mendekati satu (1) maka dapat dikatakan semakin kuat model tersebut menerangkan hubungan variabel bebas terhadap variabel terikat. Sebaliknya jika $\left(\mathrm{R}^{2}\right)$ 
makin mendekati nol (0) maka semakin lemah pengaruh variabel bebas terhadap variabel terikat.

\section{HASIL DAN PEMBAHASAN}

\section{Uji Validitas}

Uji validitas dilakukan dengan melihat korelasi bivariate antara masing-masing skor infikator dengan total skor konstruk atau variabel. Abapila korelasi masing-masing skor pertanyaan dengan skor total menunjukkan hasil yang signifikan atau kurang dari 0,05 maka item pernyataan dikatakan valid.

Tabel 3. Hasil Uji Validitas

\begin{tabular}{|c|c|c|c|c|}
\hline Pernyataan & Sig (2-tailed) & & $\alpha$ & Keterangan \\
\hline \multicolumn{5}{|c|}{ Persepsi kualitas } \\
\hline X.1.1 & 0,000 & $<$ & 0,05 & valid \\
\hline x.1.2 & 0,000 & $<$ & 0,05 & valid \\
\hline X.1.3 & 0,000 & $<$ & 0,05 & valid \\
\hline X.1.4 & 0,000 & $<$ & 0,05 & valid \\
\hline \multicolumn{5}{|l|}{ Nama merek } \\
\hline X.2.1 & 0,000 & $<$ & 0,05 & valid \\
\hline x.2.2 & 0,000 & $<$ & 0,05 & valid \\
\hline x.2.3 & 0,000 & $<$ & 0,05 & valid \\
\hline X.2.4 & 0,000 & $<$ & 0,05 & valid \\
\hline \multicolumn{5}{|c|}{ Brand awareness } \\
\hline X.3.1 & 0,000 & $<$ & 0,05 & valid \\
\hline x.3.2 & 0,000 & $<$ & 0,05 & valid \\
\hline x.3.3 & 0,000 & $<$ & 0,05 & valid \\
\hline x.3.4 & 0,000 & $<$ & 0,05 & valid \\
\hline \multicolumn{5}{|c|}{ Keputusan pembelian } \\
\hline y. 1 & 0,000 & $<$ & 0,05 & valid \\
\hline y. 2 & 0,000 & $<$ & 0,05 & valid \\
\hline y.3 & 0,000 & $<$ & 0,05 & valid \\
\hline y.4 & 0,000 & $<$ & 0,05 & valid \\
\hline
\end{tabular}

Berdasarkan hasil uji validitas diketahui bahwa seluruh nilai sig 2-tailed lebih kecil daripada 0.05 , sehingga kuisioner yang digunakan dinyatakan valid.

\section{Uji Reliabilitas}

Uji reliabilitas digunakan untuk mengukur suatu kuesioner yang merupakan indikator dari variabel atau konstruk. Suatu kuesioner dinyatakan reliabel atau handal jika jawaban seseorang terhadap pernyataan adalah konsisten atau stabil dari waktu ke waktu. 
Tabel 4. Hasil Uji Reliabilitas

\begin{tabular}{lllll}
\hline No & Variabel & Cronbach's Alpha & & Cutt off \\
\hline 1 & Persepsi Kualitas & 0,688 & $>$ & 0.6 \\
2 & Nama Merek & 0,690 & $>$ & 0.6 \\
3 & Brand Awareness & 0,711 & $>$ & 0.6 \\
4 & Keputusan Pembelian & 0,700 & $>$ & 0.6 \\
\hline
\end{tabular}

Hasil uji reliabilitas menunjukkan bahwa semua variabel mempunyai nilai cronbach's alpha di atas 0.6, sehingga kuesioner dinyatakan handal atau reliabel.

\section{AnalisisRegresi Linier Berganda}

Analisis Regresi Linear Berganda merupakan salah satu analisis yang bertujuan untuk mengetahui pengaruh suatu variabel terhadap variabel lain. Jika dalam persamaan regresi hanya terdapat salah satu variabel bebas dan satu variabel terikat, maka disebut sebagai regresi sederhana, sedangkan jika variabelnya bebasnya lebih dari satu, maka disebut sebagai persamaan regresi berganda (Priyatno, 2010).

Tabel 5.Hasil Analisis Regresi Berganda

\begin{tabular}{lll}
\hline No & Variabel & Koefisien \\
\hline 1. & Konstanta & 1,356 \\
2. & Persepsi kualitas & 0,165 \\
3. & Nama merek & 0,263 \\
4. & Brand Awareness & 0,488 \\
\hline
\end{tabular}

Variabel nilai koefisien variabel persepsi kualitas sebesar 0,165 menunjukkan jika nilai variabel persepsi kualitas meningkat sebesar satu satuan maka keputusan pembelian akan meningkat sebesar 0,165 satuan, dengan asumsi variabel nama merek dan brand awareness dalam keadaan konstan atau tidak mengalami perubahan. Nilai koefisien tersebut juga mengindikasikan bahwa persepsi kualitas memiliki pengaruh positif terhadapkeputusan pembelian, artinya jika persepsi kualitas semakin baik maka keputusan pembelian konsumen pada produk sabun cuci pakaian akan semakin meningkat. 
Nilai koefisien variabel nama merek sebesar 0,263 menunjukkan jika nilai variabel nama merek meningkat sebesar satu satuan maka nilai variabel keputusan pembelian akan meningkat sebesar 0,263 satuan, dengan asumsi variabel persepsi kualitas dan brand awareness dalam keadaan konstan atau tidak mengalami perubahan. Nilai koefisien tersebut juga mengindikasikan bahwa nama merek memiliki pengaruh positif terhadap keputusan pembelian, artinya jika nama merek semakin meningkat maka keputusan pembelian konsumen pada produk sabun cuci pakaian rinso akan semakin meningkat.

Nilai koefisien variabel brand awareness sebesar 0,488 menunjukkan jika nilai variabel brand awareness meningkat sebesar satu satuan maka keputusan pembelian akan meningkat sebesar 0,488 satuan, dengan asumsi variabel persepsi kualitas dan nama merek dalam keadaan konstan atau tidak mengalami perubahan. Nilai koefisien tersebut juga mengindikasikan bahwa brand awareness memiliki pengaruh positif terhadapkeputusan pembelian, artinya jika brand awareness semakin meningkat maka keputusan pembelian konsumen pada produk sabun cuci pakaian rinso akan semakin meningkat.

\section{Analisis Koefisien Determinasi}

Koefisien Determinasi merupakan besaran yang menunjukkan besarnya variasi variabel dependen yang dapat dijelaskan oleh variabel independennya. Dengan kata lain, koefisien determinasi ini digunakan untuk mengukur seberapa jauh variabel-variabel bebas dalam menerangkan variabel terikatnya. Hasil analisis koefisien determinasi menunjukan nilai Adjusted $R$ Square $\left(\mathrm{R}^{2}\right)$ sebesar 0,597 yang berarti 59,7\% keputusan pembelian produk sabun cuci pakaian rinso dipengaruhi oleh persepsi kualitas, nama merek dan brand awareness. Sedangkan sisanya 40,3\% dipengaruhi oleh variabel lain diluar model atau persamaan, seperti celebrity endorser, promosi, iklan televisi dan lainlain.

\section{Pembahasan}

\section{Pengaruh Persepsi Kualitas Terhadap Keputusan Pembelian.}

Hasil analisis data yang telah dilakukan dapat diperoleh taraf signifikasi 0,016 lebih kecil dari 0,05 dan $t$ hitung $(2,458)>t$ tabel $(1,664)$ menunjukkan bahwa nilai koefisien variabel persepsi kualitas 0,165 , ini berarti hipotesis yang menyatakan persepsi 
kualitas berpengaruh secara signifikan terhadap keputusan pembelian. Hal ini membuktikan bahwa persepsi kualitas mempunyai pengaruh terhadap keputusan pembelian sabun cuci Rinso pada mahasiswa Fakultas Ekonomi Angkatan 2014 Universitas Muhammadiyah Jember.

\section{Pengaruh Nama Merek Terhadap Keputusan Pembelian}

Hasil analisis data yang telah dilakukan dapat diperoleh taraf signifikasi 0,009 lebih kecil dari 0,05 dan $\mathrm{t}$ hitung $(2,659)>\mathrm{t}$ tabel $(1,664)$ menunjukkan bahwa nilai koefisien variabel nama merek 0,263 , ini berarti hipotesis yang menyatakan nama merek berpengaruh secara signifikan terhadap keputusan pembelian. Hal ini membuktikan bahwa nama merek mempunyai pengaruh terhadap keputusan pembelian sabun cuci Rinso pada mahasiswa Fakultas Ekonomi Angkatan 2014 Universitas Muhammadiyah Jember.

\section{Pengaruh Brand Awareness Terhadap Keputusan Pembelian}

Hasil analisis data yang telah dilakukan dapat diperoleh taraf signifikasi 0,000 lebih kecil dari 0,05 dan $t$ hitung $(5,066)>t$ tabel $(1,664)$ menunjukkan bahwa nilai koefisien variabel brand awareness 0,488 , ini berarti hipotesis yang menyatakan brand awareness berpengaruh secara signifikan terhadap keputusan pembelian. Hal ini membuktikan bahwa brand awareness mempunyai pengaruh terhadap keputusan pembelian sabun cuci Rinso pada mahasiswa Fakultas Ekonomi Angkatan 2014 Universitas Muhammadiyah Jember.

\section{KESIMPULAN DAN SARAN}

\section{Kesimpulan}

Berdasarkan hasil analisis yang telah dilakukan pada penelitian ini, naka dapat ditarik kesimpulan sebagai berikut :

1. Hasil pengujian hipotesis telah membuktikan terdapat hubungan positif dan signifikan persepsi kualitas terhadap keputusan pembelian sabun cuci rinso pada Mahasiswa Fakultas Ekonomi Angkatan 2014 Universitas Muhammadiyah Jember. Hal ini berarti semakin baik persepsi kualitas yang diberikan kepada konsumen maka akan meningkatkan keputusan pembelian konsumen.

2. Hasil pengujian hipotesis telah membuktikan terdapat hubungan positif dan signifikan nama merek terhadap keputusan pembelian sabun cuci Rinso pada 
Mahasiswa Fakultas Ekonomi Angkatan 2014 Universitas Muhammadiyah Jember. Hal ini berarti semakin baik nama merek yang diberikan kepada konsumen maka akan meningkatkan keputusan pembelian konsumen.

3. Hasil pengujian hipotesis telah membuktikan terdapat hubungan positif dan signifikan Brand Awareness terhadap keputusan pembelian sabun cuci Rinso pada Mahasiswa Fakultas Ekonomi Angkatan 2014 Universitas Muhammadiyah Jember. Hal ini berarti semakin tinggi brand awareness pada konsumen maka akan meningkatkan keputusan pembelian konsumen.

\section{Saran}

Berdasarkan hasil penelitian dan kesimpulan yang telah disajikan, maka selanjutnya peneliti menyampaikan saran-saran yang kiranya dapat memberikan manfaat bagi pihak-pihak yang terkait aras hasil penelitian ini. Adapun saran-saran yang dapat disampaikan adalah sebagai berikut :

1. Sebaiknya perusahaan Unilever memperhatikan persepsi kualitas konsumen, karena pengaruh terbesar terdapat pada variabel persepsi kualitas. Banyaknya produk sabun cuci yang bermunculan yang bermacam-macam membuat konsumen mempunyai banyak pilihan dalam memutuskan pembelian.

2. Nama merek juga mempunyai pengaruh besar terhadap keputusan pembelian, jadi perusahaan harus benar-benar mempertimbangkan atas nama merek yang akan dikeluarkan.

3. Brand Awareness berpengaruh signifikan terhadap keputusan pembelian artinya perusahaan Unilever harus terus menjaga dan mempertahankan produknya supaya selalu diingat di benak konsumen.

\section{Rekomendasi}

Dalam penelitian ini variabel yang digunakan adalah persepsi kualitas, nama merek dan Brand Awareness. Untuk penelitian selanjutnya disarankan menggunakan variabel yang berbeda dalam penelitian.

\section{DAFTAR PUSTAKA}

Arikunto, S. 2010. Prosedur penelitian : Suatu Pendekatan Praktik. (Edisi Revisi). Rineka Cipta. Jakarta 
Arif , Rahman, 2010. Strategi DaHXyat Marketing Mix. Jakarta : Trans Media.

Aaker, D. A. 2013. Manajemen Pemasaran Strategis. (Edisi 8). jakarta: Salemba Empat.

Bimal, Anjum, Dr, Sukhwinder Kaur Dhanda and Sumeet Nagra, 2012. Impact of Celebrity Endorsed Advertisiments on Consumers. Asia Pacific Journal of Marketing \& Management Review. 1 (2): h: 22-33.

Choy, Johnn Yee dan Ng Cheng San, 2011, Consumers' Perceived Qua-lity, Perceived Value and Perceived Risk Towards Purchase Decision on Automobile American Journal of Economics and Business Administration 3(1): 47-57, 2011

Ferrinadewi, Erna, 2008. Merek dan Psikologi Konsumen, Edisi Pertama, Graha Ilmu,Yogyakarta

Firdaus, Firwan F, 2015.PengaruhKesadaran Merek,Persepsi Kualitas,Dan Promosi Periklanan Terhadap Keputusan Pembelian Handphone Samsung, Semarang : Universitas Diponegoro.

Fahmi. Z, Reza. 2016. Pengaruh Persepsi Kulitas Produk, Kesadaran Merek, Fitur Produk, dan Harga terhadap Keputusan Pembelian Ponsel Xiaomi di Surabaya. Surabaya : Sekolah Tinggi Ilmu Ekonomi Perbanas.

Ghozali, Imam, 2009. Aplikasi Analisis Multivariate dengan Program SPSS. : UNDIP, Semarang.

Harmani, 2008. Pengaruh Pelayanan dan Fasilitas Terhadap Keputusan Konsumen Berbelanja Di Pasar Turi Baru Surabaya, Jurnal Ekonomi Bisnis dan Sosial (JEB's), Vol 8, No 2.

Inayati, Laili, S. Dewi Urip, W, 2017. Pengaruh Kesadaran Merek, Persepsi Kualitas, Asosiasi Merek, Dan Periklanan Terhadap Keputusan Pembelian. Jurnal Ilmu dan Riset Manajemen Vol 6, No 4.

Kotler, Philip, 2008. Manajemen Pemasaran, Edisi Milenium diterjemahkan Benyamin Molan, PT. Prenhallindo, Jakarta

Kotler, Philip dan Kevin Lane Keller, 2008. Manajemen Pemasaran, Jilid 1,Penerbit Erlangga. Jakarta.

Kotler, Philip dan Gary Amstrong, 2012.Prinsip-prinsip pemasaran, Edisi ke 13, Jilid 1. Jakarta: Erlangga

Kumalasari, Puti, 2013. Analisis Pengaruh Brand Awareness dan Brand Image terhadap Brand Equity dan dampaknya pada minat beli konsumen Produk Placement Mie Instan Indomie di Dalam Film 5 cm. Semarang : Universitas Diponegoro. 
Lee, G. C \& Leh, F. C. Y. 2011. Dimensions of Customer -Based Brand Equity: A Study on Malaysian Brands. Jounal of Marketing Research and Case Study.

Mayasari Lusi, I, 2011.Analisis Pengaruh Citra Merek, Persepsi Terhadap Kualitas, Nama Merek, Dan Brand Awareness Terhadap Keputusan Pembelian Sabun Pencuci Pakaian Bubuk Attack. Semarang : Universitas Diponegoro.

Moisescu, 2013, The Importance Of Brand Awareness In Consumers'Buying Decision And Perceived Risk Assessment, Babeş-Bolyai Univer-sity OfCluj Napoca,Management and Marketing 7(1), 103-110

Natoradjo, S. 2011. Event Organizer Dasar-Dasar Event Management. Jakarta: PT.Gramedia Pustaka Utama.

Okta, Ambarini Nurillah, Nurul Qomariah dan Anwar, 2016. Pengaruh Citra Merek Terhadap Keputusan Pembelian Smarthpone Merek Samsung Di Rudy Cell Komplek Mutiara Jember. Jurnal Penelitian Ipteks, jurnalunmuhjember.ac.id.

Prayitno, Duwi, 2010. Paham Analisis Data Statistik Dengan SPSS. Mediakom, Yogyakarta.

Pane ,Oon Boy M S dan Endang Sulistya Rini.2011.” Pengaruh Brand Equity Flash Disk Merek Kingston Terhadap Keputusan Pembelian “Jurnal Ekonom, Vol 14, No 3, Juli tahun 2011.

Radder L. and W. Huang, 2008, 'High-Involvement and Low-involvement Product : A Comparison of Brand Awareness Among Students at a South African Universitye, Journal of Fashion Marketing and Management, Vol.12, No.2.

Sugiyono, 2008. Metode Penelitian Kuantitatid Kualitatif Dan R \& D. Bandung: Alfabeta

Setyaji, Wahyu B, 2008, „AnalisisPengaruh Citra Merek, Perceived Quality, dan Iklan Terhadap Keputusan Pembelian Shampoo Sunsilk di Kota Semarange,Skripsi Tidak Dipublikasikan, Fakultas Ekonomi, Universitas Diponegoro, Semarang.

Supranto, 2008. Statistik Teori dan Aplikasi. Penerbit Erlangga, Jakarta

Sadat, Andi M, 2009,Brand Belief : Strategi Membangun Merek Berbasis Keyakinan, Jakarta : Salemba Empat.

Swastha, Basu. 2010.Manajemen Penjualan: Pelaksanaan Penjualan, BPFE-Yogyakarta.

Tambunan, Krystia, 2012. Analisis Pengaruh Citra Merek, Persepsi Kualitas dan Harga terhadap Keputusan Pembelian Bandeng Resto.Semarang : Universitas Diponegoro 
Vranesevic, Tihomir, 2008, The Effect of the Brand on Perceived Quality of Food Products', British Food Journal, Vol.105, No.11, p.811-825.

Yaseen,Tahira,Gulzar dan Anwar. 2011, Impact of Brand Awareness, Perceived Quality and Customer Loyalty on Brand Profitability and Purchase Intention: A Resellers' View, Interdiciplinary Joural of Contemporary Research Bussi-ness, Vol 3-8

Valarie A. Zeithaml \& Mary Jo Bitner. 2008., Service Marketing. The McGraw Hill Companies, Inc

http://www.topbrand-award.com/top-brand-survey/survey-result/topbrand-result-2016/

http://www.topbrand-award.com/top-brand-survey/survey-result/topbrand-result-2017/ 